\title{
Harold Wellman and the Alpine Fault of New Zealand
}

\author{
Emeritus scientist, GNS Science, P.O. Box 30-368, Lower Hutt, New Zealand. E-mail: s.nathan@xtra.co.nz.
}

The name of Harold Wellman (Fig. 1) is closely associated with the Alpine Fault of New Zealand as well as the study of strike-slip faults world wide. After recognising the Alpine Fault in 1941-42, Wellman continued to study it for the next 40 years, and this paper traces the evolution of his ideas on a huge fault that is now recognised as part of a major plate boundary.



Figure 1. Harold Wellman working as a surveyor in the 1930s. His theodolite is now on display at Te Papa Tongarewa, the Museum of New Zealand.

\section{Introduction}

The $850 \mathrm{~km}$-long Alpine Fault of New Zealand is one of the world's great strike-slip faults. Bisecting the South Island, it forms the western edge of the Southern Alps (Fig. 2), and is clearly visible from space. Today it is regarded as forming a section of the boundary between the Australian and Pacific tectonic plates, separating a westward-dipping subduction zone to the north from an eastwarddipping zone to the south.

Although the Alpine Fault is clearly marked in the topography, it was not recognised until first described by Harold Wellman and R. W. (Dick) Willett in 1942. For the next forty years, growing understanding of the Alpine Fault was linked with the name of Harold Wellman. Apart from mapping the fault with Willett, he recognised its major strike-slip offset of 480 kilometres, and demonstrated that most of the strike-slip movement was of late Cenozoic age. Most importantly, he showed how the Alpine Fault was part of a major plate boundary and developed ideas about the relative motions and interactions of the adjacent plates in New Zealand. Wellman's ideas evolved during this period, and it is possible to trace his changing ideas through the papers he wrote.

\section{Harold Wellman (1909-1999)}

The son of a sailor, Harold Wellman was brought up in Somerset, England. His family moved to New Zealand in 1927 when he was a teenager, and he obtained a job as a surveyor's assistant. Although he had qualified as a surveyor by 1932, there were no jobs available in his field during the depression. He earned his living for a period as a gold prospector on the remote western side of the South Island, which sparked a lifelong interest in geology. Obtaining a job as a geophysical



Figure 2. Map of the New Zealand region, showing the land area and bathymetry of the surrounding continental shelf. The Alpine Fault cuts obliquely across the South Island, forming the western edge of the Southern Alps. Recent oceanographic work has shown that the fault continues for several hundred kilometres south of New Zealand. Small ' $x$ ' indicates outcrops of a distinctive belt of steeply-dipping Permian that have been offset 480 kilometres by strike-slip movement on the Alpine Fault. 
assistant with the Geological Survey in 1934, he studied geology part-time at university in Wellington, graduating with an MSc in 1940.

Geomorphologist Charles Cotton (1885-1970) was the only geology lecturer at Victoria University College in the 1930s, and clearly influenced Wellman with his belief that most landscapes reflect tectonic and climatic influences. In later years many people were amazed at Wellman's ability to "read" geology from the landscape a legacy from Cotton's early training, and a characteristic of many New Zealand-trained geologists.

During World War 2, Wellman was involved in prospecting for strategic minerals, often in isolated, mountainous areas. For a decade after the war he worked on a number of Geological Survey projects, including coal exploration, Cretaceous stratigraphy, and the identification of active faults. In 1957 he moved to Victoria University in Wellington where he pioneered the study of what is now called neotectonics. As the concepts of plate tectonics became emerged in the late 1960s, he played a leading role in showing how New Zealand's geological structure and history was related to its position on a major plate boundary.

Wellman's life is outlined in Harold Wellman: a man who moved New Zealand (Nathan 2005). Although known in his lifetime as the man who discovered the Alpine Fault, this structure was never a topic a topic that he worked on for more than a few weeks at a time. Nevertheless, Wellman returned to the Alpine Fault many times as he pondered tectonic issues about large strike-slip faults.

\section{Why was the Alpine Fault not recognised earlier?}

The overall geological features of New Zealand had been revealed by reconnaissance surveys as early as the 1860s. James Hector (18341907) produced the first national geological map in 1865 based on all the information that was then available. Although it was clear that the western edge of the Southern Alps was a relatively straight line, there was no suggestion then or for many years later that it was a major fault.

The western side of the South Island was remote, and little visited. Charles Douglas (1840-1916), who explored the region in the later decades of the $19^{\text {th }}$ century, produced a detailed topographic map with observations of geology plotted on it, but he was mainly interested in mineral prospects and did not recognise a fault along the western edge of the mountains.

With the start of systematic geological mapping by the New Zealand Geological Survey in 1905, efforts were concentrated on the detailed mapping of clearly-defined areas called subdivisions, and geologists were discouraged from looking further afield than their assigned areas. In mapping the Mikonui subdivision, which covered the area between Hokitika and Ross, P. G. Morgan (1908) recognised a large fault on the western side of the mountains that he called the Gregory Valley (after J.W. Gregory who had recognised that the African rift zone was caused by faulting), but the extent of this fault outside the subdivision was uncertain.

\section{Part 1: Mapping the Alpine Fault (1941-42)}

During World War 2 there were shortages of minerals that had previously been imported. The unavailability of mica, then a critical component of some radio components, led to a hurried examination of the few known mica deposits. One of these had been identified many years earlier in a remote part of South Westland by Douglas. Wellman was selected to visit the area because of his knowledge of that part of New Zealand from his gold mining days. He was accompanied by Dick Willett, another young geologist (who was later to become Director of the New Zealand Geological Survey). Because the geology of the region was poorly known, Dr John Henderson (then Director of the Survey) told them to keep their eyes open and record what they could of the geology.

The two geologists travelled to Hokitika in August 1941, where they examined the map previously prepared by Douglas, and Wellman copied the geological observations on to his own map. They were also aware of Morgan's mapping, and were interested to see how far they could trace the 'Gregory Valley'.

As they had no transport, they managed to hitch a ride on the back of an open-deck truck. The weather was clear, and the view of the mountain front was spectacular. It didn't take long to realise that the 'Gregory Valley' could be readily traced southwards. It seemed to be a single, linear fault separating granite to the north-west from schist of the Southern Alps to the south-east. They found several exposures of the fault itself where the rock was pulverised, and Wellman noted that, "The broken schist looked like the result of explosions, or perhaps we were seeing the heart of old earthquakes" (Nathan, 2005, p. 75).

By the time they reached the settlement of Haast on the plains west of the fault, they realised that they had been following a huge fault that was at least 200 kilometres long, and had started to call it the Alpine Fault. When projected on the topographic map it seemed likely to continue at least another $100 \mathrm{~km}$ southwards to the coast of Fiordland. They decided to extend their trip to see if they could follow the fault, and managed to trace it as far south as Lake McKerrow.

\section{The first description of the Alpine Fault}

Dr Henderson did not query their long absence when Wellman and Willett returned to the office at the beginning of October 1941, but he was keen to see the results of their work written up promptly. Although Willett was sent to do other work (and does not reappear in the story of the Alpine Fault), Wellman spent October and November in the office, writing a report on the mica as well as two papers on the geology of South Westland. The first paper, which described the Alpine Fault, was completed and submitted for publication on 10 November 1941 — only five weeks after they returned from fieldwork. Although written rapidly, Wellman \& Willett (1942) remains one of the classics of New Zealand geology. A geological map at a scale of ten miles to the inch summarised the geological data from the trip as well as results from previous work (Figs. 3 and 4). It was a major geological reinterpretation, for the first time recognising the Alpine Fault as the boundary between two different types of geology (which would today be called terranes).

Because the writers expected some opposition to their concept of the Alpine Fault as a single major fracture along the western edge of the Southern Alps, they took care to list and justify the evidence for mapping and identifying the Alpine Fault under five headings:

(a) The presence of a scarp or sudden but regular change in summit height;

(b) Wide crush zones with slips and rapid erosion; 




Figure 3. Part of a map of south Westland (originally at a scale of 10 miles to one inch) that accompanied the paper by Wellman and Willett (1942) when the Alpine Fault was described for the first time. Note the insert map (bottom left) which identified a small lateral offset of streams - very daring for its day, but virtually ignored at the time.

(c) Subsequent rivers flowing along co-linear courses parallel to the trend of the Alps, connected by low passes;

(d) Changes in rock type;

(e) Offsetting of river courses.

Although the paper is based on reconnaissance mapping and a good deal of speculation, the position of the Alpine Fault on their map is little different to that recognised today. To the surprise of Wellman and Willett there was almost immediate acceptance of their structural interpretation within the geological community, including leading academics such as W.N. Benson (1885-1957) and Cotton.

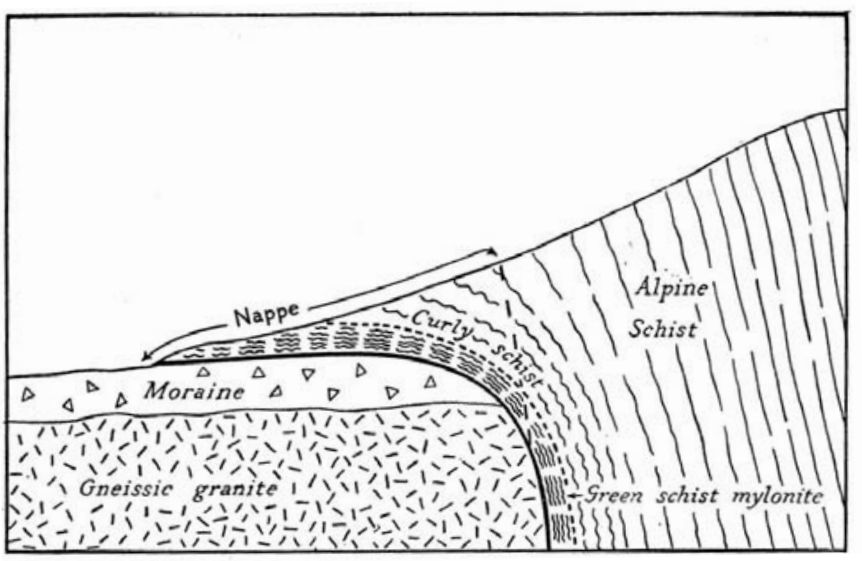

Figure 4. Although the Alpine Fault appeared straight on a small scale map, in outcrop there was often small scale overthrusting, explained by Wellman (1955b) as small gravity-driven nappes (which he called 'napplets')
But one aspect of their paper was not accepted —or rather ignored. Wellman and Willett had noted that there was a consistent offsetting of many of the rivers of about a mile, and suggested that this was due to lateral offsetting along the fault. Although this now seems obvious, it was largely ignored at the time because of a reluctance to recognise any horizontal (strike-slip) movement on faults.

Wellman did little further work on the Alpine Fault again during the war years, when he was fully occupied in economic projects. In 1947 the Geological Survey produced a new national geological map at 1:1 million scale. By today's standards it is a simple map, but the overall pattern of rock units was similar to that which is currently recognised. The full extent of the Alpine Fault, cutting obliquely across the South Island was shown for the first time (although a fault was not mapped or named).

\section{Part 2: A large horizontal offset on the Alpine Fault (1948-49)}

Looking at the geological map of the South Island today, it seems obvious that the opposite ends of the Alpine Fault have been offset by several hundred kilometres. In the 1940s, however, this was beyond imagination to most earth scientists.

In 1946 Wellman was given a new project. As an experienced geologist, he was asked to resolve long-standing stratigraphic problems about the relationships of Permian and Triassic rocks. He was to work on what was known as the "Maitai Problem" because of doubts over the age of a narrow belt of Maitai rocks (Permian/Triassic) in the Nelson area and their relationship to the widespread greywackes of the Southern Alps. Wellman spent two summers mapping around Nelson, and recognised a narrow, steeply-dipping belt of distinctive 
Maitai rocks and associated ultramafics that could be traced along strike for over 100 kilometres until abruptly cut off by the Alpine Fault. He wondered if Maitai rocks would be found nearby on the opposite side of the fault, and then realised that there were similar rocks 480 kilometres (300 miles) away at the other end of the Alpine Fault which had never been mapped or described. Later in life, Wellman recalled that the idea came to him on a wet Sunday afternoon while sitting at the dining room table. He immediately took a pair of scissors and cut the newly published geological map along the Alpine Fault to check if the opposite sides matched (Nathan 2005, p. 116). They did!

At that stage Wellman had little personal knowledge of the rocks at the southern end of the Alpine Fault, but in late 1948 he was joined in the field by George Grindley (Fig. 5), a young graduate who had recently completed an MSc thesis at Otago University on the Maitai and associated rocks at the critical area in Otago. He and Wellman compared notes, and immediately agreed that the formations, called



Figure 5. Harold Wellman (left) and George Grindley relaxing in a warm spring on the Alpine Fault, near Haupiri.

by different names at opposite ends of the fault could be matched unit by unit.

\section{Pacific Science Congress (February 1949)}

Wellman presented his ideas at a session of the Pacific Science Congress in February 1949. The Congress was a major event, as New Zealand scientists had been isolated for almost a decade, during and after World War 2. A large group of New Zealand geologists attended, as well as many visitors from around the Pacific, including US seismologists Gutenberg and Richter. Wellman's talk made a big impact, and was remembered for many years. Ross Taylor, then a young graduate student at Canterbury University College (and later Professor of Geochemistry at Australian National University, Canberra) recalled the occasion (Nathan, 2005, pp.118-119):

"The highlight of the meeting was Harold Wellman. Word had got around about his ideas, and the room was full. He displayed a large handmade geological map of the South Island, and then, after talking for a while, suddenly proceeded to slide southern Westland 300 miles along the Alpine Fault to match the strata near Nelson. It was a dramatic moment that I have never forgotten. It made me realise that there was much more to geology than I had learnt already. Geology at that time was a very conservative subject and perhaps the most lasting effect on me was to hear someone bold enough to put forward such a novel idea."

Afterwards there were plenty of arguments as most New Zealand geologists were sceptical about accepting major strike-slip movement on faults. However, being aware of evidence for strike-slip movement on the San Andreas Fault, Gutenberg and Richter were more receptive, and Richter's textbook, Elementary Seismology, subsequently referred to Wellman's "bold suggestion" of 480 kilometres of movement on the Alpine Fault (Richter, 1958).

\section{Acceptance of the $480 \mathrm{~km}$ offset}

Unfortunately Wellman did not write a paper after the conference explaining his idea on the $480 \mathrm{~km}$ offset on the Alpine Fault, although he did refer to it in passing in later papers (e.g. Wellman, 1955), and his idea was widely debated for the next decade.. In retrospect, a paper probably would not have made much difference as the arguments were largely philosophical. Were substantial strike-slip movements on major faults possible?

Wellman did present all the evidence in for the $480 \mathrm{~km}$ offset in the maps accompanying his Structural Outline of New Zealand, published by the Department of Scientific and Industrial Research (DSIR) (Wellman, 1956), but it is extraordinary that there is no mention of it in the text. Although it cannot be verified, I have a strong suspicion that all mention of large strike-slip offset was edited out by DSIR editors as being too controversial for an official government publication.

By the early 1960s there was general acceptance of the $480 \mathrm{~km}$ offset, especially as it was supported by later mapping of the rocks at the opposite ends of the Alpine Fault. Beck (1964) gave a comparison of the Maitai rocks at opposite ends of the fault. Max Carman, a petrologist from the University of Houston, Texas, spent a year in New Zealand in 1963, and undertook a detailed comparison of the rocks at opposite ends of the Alpine Fault (Carman, 1967). This excellent paper has been little quoted. There would have been much more interest if it had been published fifteen years earlier, but by 1967 the topic was no longer controversial.

\section{Part 3: When did the Alpine Fault move? (1952-1963)}

In 1948, soon after identifying the $480 \mathrm{~km}$ offset on the Alpine Fault, Wellman thought that the timing of movement was ancient, probably Mesozoic (Nathan, 2005, p.117). But he soon started to have second thoughts.

In January 1952, while examining some features of the Alpine Fault he had noted on aerial photographs, Wellman discovered a sequence of faulted Holocene terraces at Maruia River., near Springs Junction (Fig. 6). As this is immediately adjacent to State Highway 7, it is the most readily accessible place to see the Alpine Fault, often visited today. There is a well-defined scarp where recent movement on the Alpine Fault has offset the ground surface. Moreover, the river has progressively cut a series of step-like terraces down to the present river bed. Wellman (1952) recognised that the older terraces had been offset more than the younger, indicating repeated Holocene movement on the Alpine Fault. He realised that mapping and interpretation of ruptures that cut the ground surface (later called 'recent traces' or 'active faults') could provide a way of analysing the most recent movements on the Alpine Fault. 




Figure 6. Sketch map of the Maruia River from Wellman's paper on the Maruia terrace sequence (Wellman, 1952). This was the first time that evidence for repeated movement on a fault had been documented in New Zealand, and it led Wellman to search for similar evidence on other faults.

This inspired Wellman to systematically scan all the available aerial photographs in the South Island for evidence of fault traces, especially evidence of multiple offsets. His compilation (Wellman 1953) contained detailed records of 309 fault traces and effectively outlined the location of the major active faults in the South Island (Fig. 7). In almost all the localities along the Alpine Fault (and also the major faults in Marlborough) the horizontal offsets were considerably greater than the vertical, and the sense of offset was consistently clockwise (dextral)

The evidence for repeated late Quaternary offset along the Alpine Fault led Wellman to estimate the rate at which movement had taken place, assuming that discrete offsets during fault rupture could be averaged over a long period. Making a simple calculation of total displacement divided by time, he concluded (Wellman 1955) that movement had probably been continuous since the Jurassic at a rate of about 0.15 inches per year $(3.8 \mathrm{~mm} /$ year). However, from the evidence of recent fault traces, he realised that horizontal movement had been considerably greater during the late Quaternary-up to 1 inch per year ( $25.4 \mathrm{~mm} /$ year), and he suggested that this indicated a considerable increase in the tempo of deformation in late Cenozoic time.

There followed considerable debate about the extrapolation and averaging of data from fault traces, and whether it was a valid way to measure strain. It was one of the first attempts in the world to quantify the movement on faults, undertaken about the same time that similar studies were starting in California. Such an approach is now regarded as routine in neotectonic studies.

Wellman returned to re-examine exposures at the southern end of the Alpine Fault in 1962-1963. Convinced by his examination of glacial features that horizontal movement had taken place throughout the Quaternary at about $25 \mathrm{~mm} / \mathrm{year}$, he concluded that the whole 480 kilometre offset could be accounted for by movement at that rate

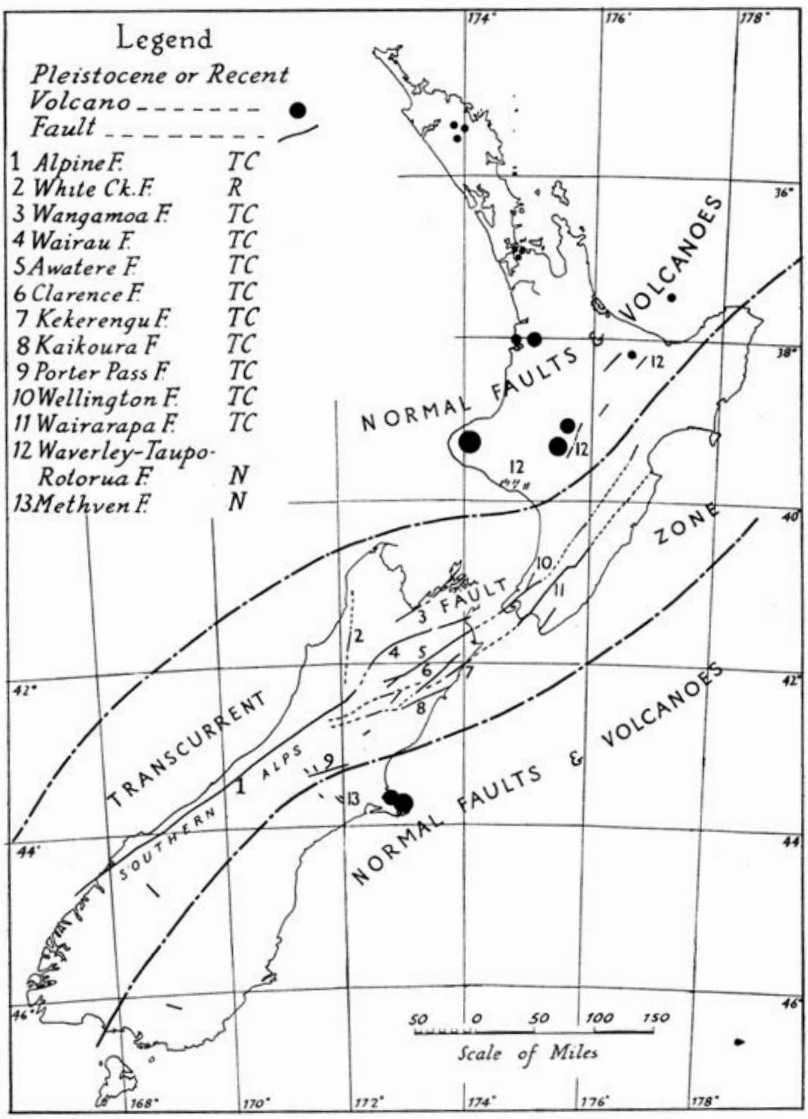

Figure 7. Map of the South Island of New Zealand showing the wide belt of strike-slip (transcurrent) faulting (Wellman, 1955a), based almost entirely on Wellman's reconnaissance examination and classification of active faults. 
over the last 15-20 million years (i.e. since the mid Miocene). While controversial at the time, this conclusion is now generally accepted.

\section{Part 4: The Alpine Fault as a plate boundary (1970-1985)}

Before the late 1960s there was no generally accepted theory that explained the working of the earth and its major tectonic features. Although Wellman had compared the Alpine Fault with other large strike-slip faults in California and south Asia, the global significance of these giant faults was unclear.

However, as is well-known, geophysical exploration of the ocean floors revealed that the earth was composed of a mosaic of large crustal plates, each moving independently. Large strike-slip faults occurred at some of the oblique plate boundaries as well as within plates. The Alpine Fault was recognised as one part of the boundary between the Australian and Pacific plates, separating the westwarddipping subduction zone in the north from an eastward-dipping zone in the south.

The concept of plate tectonics appealed enormously to Wellman, not only because it explained present-day deformation, but also because it provided a model that could be used to explain the past history of the New Zealand region. He believed that a significant component of the strain in the New Zealand region was being accommodated on faults for which there was evidence of repeated Holocene movement, and this led him to develop a variety of mechanical models in which the Alpine Fault inevitably played a major part.

In May 1978 a workshop on the Origin of the Southern Alps was held in Wellington. Wellman contributed a paper: "An uplift map for

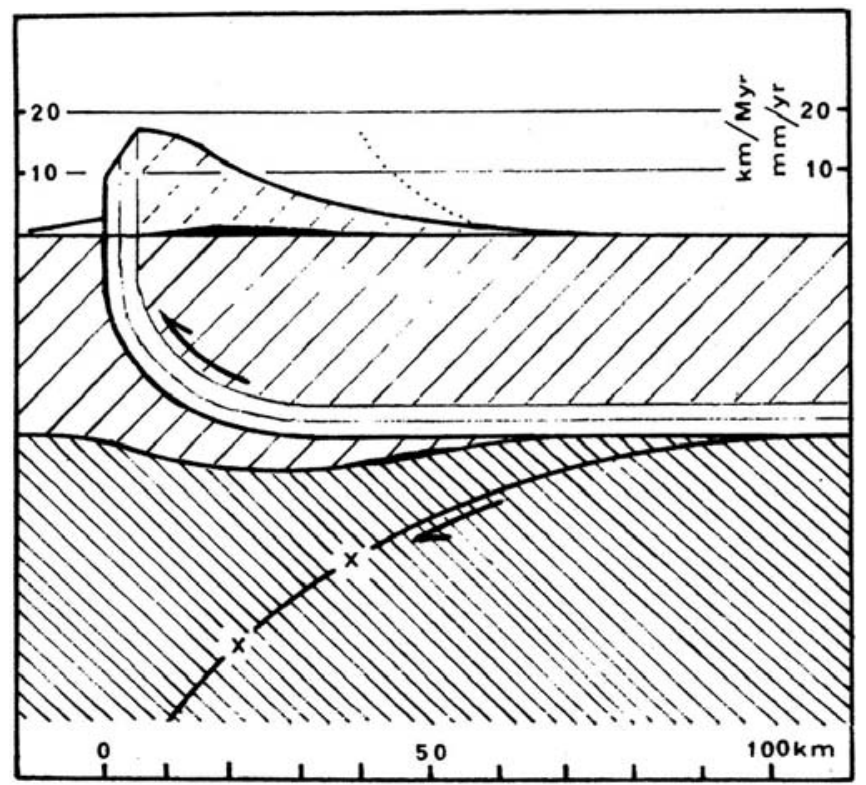

Figure 8. Diagrammatic cross section illustrating how the development of the Southern Alps was related to a wide zone of deformation across the plate boundary, and an inferred change in orientation of the Alpine Fault at depth (Wellman 1979). the South Island of New Zealand and a model for the uplift of the Southern Alps" which was subsequently published (Wellman, 1979). It turned out to be Wellman's last major paper, but it is still regularly cited.

The uplift map was a synthesis of ideas and techniques that Wellman and his PhD students had developed in the preceding decade to measure uplift rates. The absence of precise survey data meant that uplift could only be measured the deformation of geological features. For example, Wellman had used sequences of terraces around glacial lakes to measure tilting within the mountains. As anticipated, the terraces were tilted upwards towards the most rapidly rising part of the Alps, immediately to the east of the Alpine Fault.

The second part of the paper involved a model to explain the uplift pattern. Wellman recognised that the upper part of the crust in the Pacific plate was effectively being obducted along the Alpine Fault. He visualised a curved fault, flattening out near the base of the crust to accommodate the westerly motion of the Pacific plate (Fig. 8). Although apparently simple, it neatly fitted the uplift pattern. In succeeding years there has been considerable deep geophysical work undertaken to try and determine the deep structure of the Southern Alps as well as GPS work to monitor continuing deformation. Thirty years later Wellman would be gratified to know that current ideas are a refined version of the simple models he proposed in the 1970s.

\section{References}

Beck, A. C., 1964. Sheet 14-Marlborough Sounds. "Geological Map of New Zealand 1:250,000": Department of Scientific and Industrial Research, Wellington.

Carman, M. F., 1967, A comparison of some Permian rocks on opposite sides of the Alpine fault, South Island, New Zealand: Transactions of the Royal Society of New Zealand (Geology), v. 6, pp. 91-130.

Nathan, S., 2005. Harold Wellman: A Man who Moved New Zealand: Wellington, Victoria University Press.

Richter, C. F., 1958, Elementary Seismology: San Francisco, Freeman.

Wellman, H. W., 1952. The Alpine Fault in detail: river terrace displacement at Maruia River: New Zealand Journal of Science and Technology, v. B33, pp. 409-414.

Wellman, H. W., 1953. Data for the study of Recent and late Pleistocene faulting in the South Island of New Zealand: New Zealand Journal of Science and Technology, v. B34: 270-288.

Wellman, H. W, 1955a, New Zealand Quaternary tectonics: Geologische Rundschau, v. 43, pp. 248-257.

Wellman, H. W. 1955b, The geology between Bruce Bay and Haast River, south Westland. New Zealand Geological Survey Bulletin 48 ( $2^{\text {nd }}$ edition), 46 pp. and geological map.

Wellman, H. W. 1956. Structural Outline of New Zealand: DSIR Bulletin $121,36 \mathrm{pp}+$ maps.

Wellman, H. W., 1979, An Uplift Map for the South Island of New Zealand and a Model for Uplift of the Southern Alps: Wellington, Royal Society of New Zealand, Bulletin 18, pp. 13-20.

Wellman, H. W. and Willett, R.W., 1942, The geology of the West Coast from Abut Head to Milford Sound-Part 1. Transactions of the Royal Society of New Zealand, v. 71: pp. 282-306.

Wellman, H. W. and Wilson, A. T., 1964, Notes on the geology and archaeology of the Martins Bay district. New Zealand Journal of Geology and Geophysics, v. 7, pp. 282-306. 